\title{
ANALISA KEEKONOMIAN TARIF LISTRIK PEMBANGKIT LISTRIK TENAGA SURYA 1 MWP BANGLI DENGAN METODE LIFE CYCLE COST
}

\author{
I.B.K. Sugirianta ${ }^{1}$, I.A.D. Giriantari ${ }^{2}$, I.N. Satya Kumara ${ }^{3}$
}

\begin{abstract}
Feed-in tariff (FIT) policy has been implemented in many countries in order to improve the utilization of renewable sources of energy as an alternative energy sources. Through Permen ESDM No. 17 in 2013, the government of the Republic of Indonesia has set the FIT policy of photo voltaic system for Solar Energy Generation (PLTS). Using this policy, the government want to attract some investors for investing in solar power generation in order to achieve an optimal value of the national energy mix in 2025 where the portion of the renewable energy are $23 \%$. The method used in calculating the electricity sales tariff is life cycle cost method, this method calculates the overall cost of a system, from planning, construction, operation \& maintenance, equipment replacement, and salvage value over the lifetime of the system. In this paper, electricity sales tariff can be found by adding a profit margin in the calculation of LCOE, and $\mathrm{LCoE}$ is total of present value LCC divided by total of present value energy generation. The result of the electricity sales tariff calculation is Rp. 2,201 / $\mathrm{kWh}$ which meets with the benchmark price in FiT. Four parameter are used to analyze the economic feasibility of this electricity sales tariff, such as IRR (Internal Rate of Return), Pay Back Period (PBP), PI (Profitability Index) and PNV (Net Present Value) methods.
\end{abstract}

Intisari-Kebijakan feed-in tariff (FiT ) telah diterapkan di banyak negara dalam rangka peningkatkan peranan sumber energi baru-terbarukan sebagai sumber energi alternatif. Melalui Permen KESDM No. 17 tahun 2013, pemerintah Republik Indonesia telah menetapkan kebijakan FiT untuk PLTS yang mempergunakan system photovoltaic. Dikeluarkannya kebijakan ini, dengan harapan dapat menarik minat para investor untuk membangun PLTS dalam rangka mencapai sasaran bauran energi nasional yang optimal dengan target sebesar $23 \%$ adalah peran energi baru-terbarukan pada tahun 2025. Metode yang dipergunakan dalam menghitung tarif penjualan listrik adalah metode Life Cycle Cost (LCC), merupakan metode yang menghitung keseluruhan biaya sebuah sistem mulai dari perencanaan, pembangunan, operasional \& maintenance, penggantian peralataan, dan salvage value selama umur hidup sistem tersebut. Tarif penjualan listrik dalam paper ini dihitung dengan menambahkan margin keuntungan pada hasil perhitungan Levelized Cost of Energy ( $\mathrm{LCoE}$ ), dan nilai LCoE adalah total present value LCC dibagi dengan total present value energi yang dibangkitkan. Hasil perhitungan mendapatkan nilai tarif penjualan listrik sebesar Rp. 2.201,/kWh yang memenuhi harga patokan tertinggi FiT. Untuk menganalisa secara ekonomi kelayakan nilai penjualaan

${ }^{1}$ Mahasiswa Magister Teknik Elektro, Program Pascasarjana Universitas Udayana, Jl. PB. Sudirman, Denpasar, Bali 80232 INDONESIA (e-mail: ibksugirianta@pnb.ac.id)

${ }^{2,3}$ Staf Pengajar Magister Teknik Elektro, Program Pascasarjana Universitas Udayana, Jl. PB. Sudirman, Denpasar, Bali80232 INDONESIA (e-mail: dayu.giriantari@unud..ac.id, satya.kumara@.unud.ac.id) listrik ini, dipergunakan 4 parameter yaitu IRR (Internal Rate of Return), Pay Back Period (PBP), PI (Profitability Indek) dan PNV (Net Present Value).

Kata Kunci-pembangkit listrik tenaga surya, feed-in tariff, levelized cost of energy, life cycle cost.

\section{Pendahuluan}

Pemerintah Repubik Indonesia telah mengatur pengelolaan energi nasional melalui KEN (Kebijakan Energi Nasional) sesuai dengan Peraturan Pemerintah (PP) nomor 79 tahun 2014. Adapun tujuan dari PP ini adalah untuk mengarahkan pengelolaan energi nasional dalam rangka mewujudkan kemandirian dan ketahanan dalam bidang energi guna mendukung keberlanjutan pembangunan nasional. Meningkatnya peranan energi baru dan terbarukan adalah salah satu sasaran dari KEN, sedangkan sebagai targetnya pada tahun 2025 tercapai bauran energi yang optimal dimana peran energi baru dan terbarukan adalah $23 \%$ dan meningkat menjadi $31 \%$ pada tahun 2050 [1].

Sumber energi baru adalah sumber energi yang dapat dihasilkan oleh teknologi baru, baik yang dihasilkan oleh sumber energi baru maupun sumber energi terbarukan, antara lain nuklir, hidrogen, gas metana batubara ( coal bed methane), batubraa tercairkan (lequified coal), dan batubara tergaskan (gasified coal). Sumber energi terbarukan adalah sumber energi yang dihasilkan dari sumber energi yang berkelanjutan jika dikelola dengan baik, antara lain panas bumi, angin, bioenergi, sinar matahari, aliran dan terjunan air, serta gerakan dan perbedaan suhu lapisan laut [1].

Salah satu sumber energi terbarukan yang tidak ada habisnya adalah sinar matahari, yang dapat dimanfaatkan sebagai sumber Pembangkit Listrik Tenaga Surya (PLTS). Di Indonesia PLTS mempunyai potensi yang cukup besar, yaitu 0,87 GW, dengan rencana pembangunan sesuai dengan Blue Print Pengelolaan Energi Nasional sebesar $80 \mathrm{MW}$ pada tahun 2010, 100 MW pada tahun 2014, 120 MW pada tahun 2016, $180 \mathrm{MW}$ pada tahu 2021 dan $400 \mathrm{MW}$ pada tahun 2024 [2].

Untuk di Bali sendiri tercatat pada 2014, jumlah pembangkit terbarukan telah mencapai $7 \mathrm{MW}$. Terdiri dari 2,1 MW fotovoltaik, $736 \mathrm{~kW}$ tenaga angin, $45 \mathrm{~kW}$ mikro hidro, dan 4,174 MW listrik dari limbah/sampah. Pembangkit terbarukan menyumbang sekitar $1 \%$ dari total kapasitas listrik di Bali [3].

Pembangunan PLTS perlu terus diupayakan agar target yang diinginkan bisa tercapai. Kebijakan feed-in tarif adalah salah satu kebijakan yang telah diambil oleh pemerintah, yaitu suatu kebijakan untuk menentukan harga jual listrik yang menggunakan sumber energi baru dan terbarukan. Melalui 
Permen ESDM No. 17 tahun 2013 tentang tata cara pembelian listrik oleh PT. PLN (Persero) dari PLTS foto voltaik. Untuk patokan harga tertinggi adalah sebesar US \$ $25 \mathrm{sen} / \mathrm{kWh}$ dan ada keistimewaan untuk PLTS yang menggunakan modul fotovoltaik dengan tingkat komponen dalam negeri minimal $40 \%$ ditetapkan patokan harga tertingginya adalah 30 sen/kWh US \$ [4]. Ashadi (2012), menganalisa penerapan harga feed-in tariff dari PLTS sistem photovoltaik melalui suatu perumusan tariff pembelian listrik mendapatkan kisaran harga Fit antara Rp. 1.987/kWh -Rp. 4.503/kWh [5].

PLTS Bangli merupakan salah satu pilot project yang telah beroperasi saat ini. Potensi optimum energi listrik per tahun yang dihasilkan PLTS Bangli dari hasil simulasi adalah 1.656 MWh, dengan PR 83,6 \%. Mulai dari 15 Februari sampai dengan 30 September 2013 produksi real energi listrik PLTS Kayubihi Bangli adalah 729,08 MWh, selisih 32,3\% dari simulasi PVSyst sebesar 1.076,94 MWh [6].

Sampai saat ini belum ditetapkan nilai tarif penjualan listrik PLTS Bangli, walaupun energi listrik telah dihasilkan dan disalurkan ke jaringan PLN. Pokok permasalahannya adalah, berapakah harga keekonomian tarif penjualan listrik PLTS Bangli, dengan memperhitungkan keseluruhan biaya yang diperlukan (Life Cycle Cost) mulai dari biaya investasi yang telah dikeluarkan, biaya manajemen pengelola, biaya operasional, pemeliharaan dan penggantian peralatan, biaya sewa lahan dan juga biaya asuransi. Termasuk didalamnya juga agar sudah memperhitungkan keuntungan yang harus didapatkan oleh pengelola dan teralokasinya dana untuk pembangunan kembali PLTS Bangli. Disisi lain, penentuan tarif harus tetap berpedoman kepada regulasi yang berlaku.

Ada dua metode yang biasa dipergunakan dalam perhitungan penentuan tarif listrik, adapun metode tersebut adalah sebagai berikut :

- Metode Biaya Pokok Penyediaan (COS/RoR) yang memperhitungkan keuntungan dalam penentuan BPP dan yang dikenal dengan istilah backward looking, menggunakan data-data yang sudah ada (historical data), dalam bentuk laporan keuangan tahunan.

- Metode Long Run Marginal Cost (LRMC), sebagai perhitungan ekonomis yang dipergunakan dalam desain tarif, yang dikenal dengan itilah forward looking ( planning)

Metode Long Run Marginal Cost telah dipergunakan dan berhasil menghitung tarif listrik di EDTL Timor Leste [7]. Metode biaya pokok penyediaan dan LRMC juga telah dipergunakan dan berhasil dalam menentukan tarif listrik [8].

Metode life cycle cost telah banyak diaplikasikan untuk perhitungan biaya pada berbagai bidang seperti, dapat dipergunakan dalam menghitung efisiensi pemakaian energi pada sebuah gedung [9], menghitung total biaya dan analisa energi pada rumah yang menggunakan sistem kombinasi energi surya. [10].

Center for Building Technology of the National Bureau of Standards for the U.S. Department of Energy [National Bureau of Standards, 1980], telah mengembangkan metode life cycle costs untuk aplikasinya pada sistem energi [11].
Dengan melihat kajian dan referensi diatas, menunjukkan bahwa $L C C$ bisa diaplikasikan pada banyak bidang, pada kajian ini $L C C$ akan dipergunakan sebagai dasar untuk menentukan harga penjualan tarif listrik.

\section{Plts BANGLI}

PLTS Bangli berlokasi di Desa Kayubihi Kecamatan Bangli Kabupaten Bangli Provinsi Bali, mempunyai kapasitas 1 MWp on gridd dengan jaringan PLN. PLTS ini didirikan oleh Pemerintah RI melalui KESDM, yang diresmikan pada tanggal 25 Pebruari 2013. Sebagai kontraktor pelaksana adalah PT. Surya Energi Indotama Indonesia (SEI) yang merupakan anak perusahaan dari PT. LEN Industri (Persero). PLTS Bangli berdiri di atas lahan seluas $18.450 \mathrm{~m}^{2}$, dimana sekitar $8.700 \mathrm{~m}^{2}$ bidang lahannya digunakan untuk ladang penangkap surya yang terdiri dari kumpulan modul surya / array sebagai penghasil energi listrik.

Mulai bulan Nopember 2013 pengelolaan PLTS Bangli sudah dihibahkan dari KESDM ke Pemerintah Daerah Tingkat II Bangli (Pemkab Bangli). Melalui Perda Kabupaten Bangli No. 5 Tahun 2013 dan Perda Kabupaten Bangli No. 25 Tahun 2013 pengelolaan PLTS Bangli dilaksanakan oleh Perusahaan Daerah Bukti Mukti Bhakti (PD-BMB) yang dimiliki oleh Pemerintah Daerah Kabupaten Bangli, Provinsi Bali. Pemkab Bangli yang telah diberikan hibah tentunya berkewajiban untuk tetap menjaga keberlanjutan operasional, perbaikan dan pemeliharaan PLTS tersebut.

PLTS Bangli merupakan kategori PLTS skala besar, sistem yang diterapkan di PLTS Bangli merupakan sistem PLTS terpusat, yang terhubung ke jaringan tanpa sistem penyimpanan/baterai (Grid-connected centralized without storage PV plant). Sistem ini terhubung ke tegangan menengah PLN dengan tegangan nominal $20 \mathrm{kV}$. Sistem PLTS Bangli menggunakan inverter konfigurasi string. Peralatan dan komponen yang digunakan pada PLTS Bangli adalah sebagai berikut :

- 278 PV array, tipe penyangga tetap (fixed support).

- 5004 modul surya jenis monocrystalline dengan daya puncak $200 \mathrm{Wp}$ per modul.

- Penyangga modul, memiliki kemiringan antara $13-15^{\circ}$.

- Inverter, tipe string 3 fasa inverter yang berjenis gridconnected inverter. Jumlah inverter 50 unit dengan kapasitas daya nominal adalah $20 \mathrm{~kW} /$ unit. Inverter ini merupakan pabrikan China dengan merk SUNGROW, tipe SG20KTL.

- Array Protection Panel berfungsi sebagai pengaman dari arus balik (reverse current) yang dapat timbul akibat tegangan baterai yang lebih tinggi di malam hari atau akibat variasi tegangan tiap array.

- Panel distribusi, digunakan 5 panel distribusi yang melayani 5 grup array (grup A, B, C, D, E).

- Transformator penaik tegangan (step up transformer),5 unit transformator penaik tegangan dari $230 / 400 \mathrm{~V}$ menjadi $20 \mathrm{kV}$.

- Penyalur petir konvensional

- Remote monitoring system, untuk menampilkan data dan informasi dari operasi sistem, alat ini sangat 

diperlukan untuk dapat menampilkan data guna mengevaluasi dan analisis dari PLTS.

- Environmental monitoring device, berfungsi untuk memonitor keadaan lingkungan.

\section{LEVELIZED COST OF ENERGY}

\section{A. Life Cycle Cost}

Model life cycle cost pada sistem energi pertama dikembangkan oleh Departement of Energy US dan diatur dalam National Bureau of Standards, 1980. Model ini mempertimbangkan total semua biaya yang relevan dari suatu sistem energi dari waktu ke waktu mulai dari biaya desain, bangunan, bahan, operasi sistem, dan komponen. Lebih khusus lagi, termasuk biaya investasi awal, operasi, biaya pemeliharaan, biaya penggantian peralatan dimasa yang akan datang, keamanan, asuransi dan juga nilai jual kembali. Dengan demikian, biaya siklus hidup sistem energi dirumuskan sebagai berikut [12]:

$$
L C C=E C+I C+S V+N F O M C+N R C+R C
$$

$$
\begin{array}{ll}
\text { Dimana : } & \\
\text { LCC } & \text { : nilai saat ini dari life cycle cost } \\
\text { EC } & \text { : nilai saat ini dari biaya energy } \\
\text { IC } & \text { : nilai saat ini dari biaya investasi } \\
\text { SV } & \text { : nilai saat ini dari salvage } \\
\text { NFOMC } & \text { : nilai saat ini dari operasi diluar bahan bakar } \\
& \text { setiap tahun berulang dan biaya pemeliharaan } \\
\text { NRC } & \text { : nilai saat ini dari operasi diluar bahan bakar } \\
& \text { tidak berulang dan pemeliharaan biaya. } \\
\text { RC } & \text { : nilai saat ini biaya berulang atau biaya } \\
& \text { tahunan }
\end{array}
$$

Biaya siklus hidup (life-cycle cost) merujuk pada penjumlahan semua biaya-biaya, baik yang berulang maupun tidak berulang sehubungan dengan produk, struktur, sistem, atau jasa selama jangka waktu hidupnya.

\section{B. Levelized Cost of Energi (LCoE)}

$L C o E$ adalah harga dimana energi listrik yang dibangkitkan dari sumber energi tertentu dapat mencapai break even selama jangka waktu tertentu. Biasanya jangka waktunya ditentukan berdasarkan waktu pakai (life time) dari sistim pembangkit tersebut

U.S. Energy Information Administration mendefinisikan LCoE sebagai berikut : levelized cost mempresentasikan nilai total dari biaya investasi, operasional \& perawatan, biaya penggantian peralatan, sewa lahan, asuransi sebuah fasilitas pembangkit yang di 'present value' kan dalam satu siklus finansial dan siklus kerja, kemudian nilai ini dikonversikan dalam cicilan tahunan dengan menambahkan perhitungan tingkat inflasi.

Definisi ini dapat diformulasikan dalam rumus $L C o E$ sebagai berikut [13] :

I.B.K. Sugirianta: Analisa Keekonomian Tarif Listrik...

$$
L C o E=\frac{I+\sum_{t=1}^{n} \frac{L C C}{(1+r)^{t}}}{\sum_{t=1}^{n} \frac{E t}{(1+r)^{t}}}
$$

Dimana :

$\mathrm{I}_{\mathrm{t}} \quad$ : biaya investasi pembangkit perioda tahun ke- $\mathrm{t}$

$\mathrm{LCC}_{\mathrm{t}}$ : Life Cycle Cost pembangkit perioda tahun ke-t

$\mathrm{r} \quad$ : nilai suku bunga yang berlaku

$\mathrm{E}_{\mathrm{t}} \quad$ : pembangkitan energi listrik yang dihasilkan (dalam kWh) pada tahun ke-t

n : umur pakai pembangkit

\section{Studi Kelayakan Ekonomi}

Untuk menganalisa secara ekonomi kelayakan nilai penjualaan tarif listrik ini, akan dianalisa dengan mempergunakan 4 (empat) parameter yaitu PI (Profitability Index), PBP (Pay Back Period), IRR (Internal Rate of Return) dan NPV (Net Present Value).

1) Pay Back Period (PBP): PBP adalah sebuah parameter yang menghitung seberapa cepat waktu yang diperlukan untuk mengembalikan suatu investasi, sehingga satuan yang dipergunakan adalah tahun, bulan dan hari.

$$
P B P=\left(\frac{\text { investasi awal }}{\text { penerimaan periodik kas bersih }}\right)
$$

Sebagai kriteria penilaiannya adalah, apabila nilai $P B P$-nya lebih panjang dari waktu yang disyaratkan maka proyek ditolak, sedangkan apabila waktunya lebih pendek maka proyek diterima.

2) Net Present Value (NPV): Parameter NPV adalah sebuah parameter dengan mempergunakan suatu tingkat bunga yang relevan untuk menghitung selisih antara nilai sekarang investasi dengan nilai sekarang penerimaan kas bersih dengan memperhitungkan operasional cash flow.

Sebagai kriteria penilaian kelayakannya adalah apabila nilai sekarang penerimaan total cash bersihnya lebih besar dari total nilai sekarang investasi maka proyek tersebut dinyatakan menguntungkan, sedangkan sebaliknya apabila nilai sekarang penerimaan lebih kecil dari nilai investasi, maka proyek tidak menguntungkan. Rumusan matematisnya adalah sebagai berikut :

- apabila NPV >0 : proyek dinyatakan layak

- apabila NPV $<0$ : proyek dinyatakan tidak layak

- apabila NPV $=0$ : proyek tidak untung $\&$ tidak rugi

$$
N P V=\sum_{t=1}^{n} \frac{B_{t}-C_{t}}{(1+i)^{t}}
$$

\section{Keterangan :}

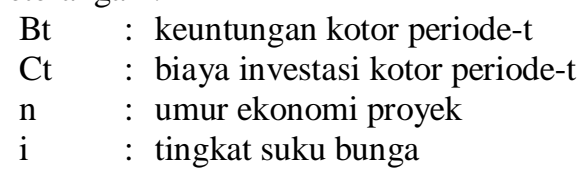

3) Internal Rate of Return (IRR): Parameter IRR adalah parameter yang dipergunakaan untuk mendapatkan tingkat p-ISSN:1693 - 2951; e-ISSN: 2503-2372 
bunga yang menyamakan total nilai sekarang penerimaan arus kas yang diharapkan dengan total nilai sekarang yang diperlukan untuk investasi. Untuk kriteria keputusannya ditentukan oleh nilai IRR yang didapatkan, jika nilai IRR lebih besar dari nilai suku bunga yang umum berlaku maka proyek diterima dan sebaliknya proyek ditolak apabila nilai IRR lebih kecil dari suku bunga yang berlaku. Formulasi IRR :

$$
I R R=i+\left\{\frac{N P V}{N P V^{1}-N P V^{2}}\left(i^{1}-i^{2}\right)\right\}
$$

Keterangan :

$$
\begin{aligned}
& \text { i : tingkat suku bunga } \\
& \mathrm{i}^{1} \quad \text { : tingkat suku bunga yang bisa menghasilkan nilai } \\
& \text { positif NPV. } \\
& \mathrm{i}^{2} \quad \text { : tingkat suku bunga yang bisa menghasilkan nilai } \\
& \text { negatif NPV } \\
& \mathrm{NPV}^{1} \text { : nilai positif net present value } \\
& \mathrm{NPV}^{2} \text { : nilai negatif net present value }
\end{aligned}
$$

4) Profitability Index atau PI: Parameter profitability index atau PI adalah perbandingan antara nilai sekarang penerimaan arus kas dengan nilai sekarang pengeluaran arus kas. Ini juga dikenal dengan nama parameter benefit cost ratio.

Sebagai kriteria dalam menentukan penerimaaan proyek ditentukan dari nilai $P I$, proyek dinyatakan diterima apabila nilai $P I$ nya sama atau lebih besar dari 1 , sedangkan sebaliknya proyek ditolak apabila nilainya lebih kecil dari 1 .

$$
P I=\frac{P V \text { Penerimaan }}{P V \text { Pengeluaran }}
$$

\section{PEMBAHASAN}

\section{A. Skenario}

Pada umumnya pembangunan PLTS adalah dilakukan oleh investor yang murni bersifat Independent Power Producer (IPP) sedangkan PLTS Bangli merupakan pilot project dari Pemerintah Republik Indonesia melalui Kementrian ESDM RI. Sebagai suatu pilot project tentunya PLTS Bangli mempunyai nilai yang berbeda jika dibandingkan dengan PLTS yang besifat IPP murni. Dengan melihat hal diatas maka pembahasan keekonomian tarif penjualan listrik PLTS Bangli ini, akan menggunakan dua skenario yaitu skenario-1 dan skenario-2.

Skenario-1, adalah dengan mengasumsikan PLTS Bangli sebagai PLTS yang murni IPP, dalam skenario-1 perhitungan LCC dalam penentuan tarif penjualan listrik dengan memasukkan biaya investasi awal yang telah ditanamkan oleh Pemerintah yaitu sebesar Rp. 25.000.000.000,-. Sedangkan skenario-2, dibuat dengan melihat bahwa PLTS Bangli adalah murni pilot project yang dihibahkan ke PemKab Bangli. Sebagai penerima hibah tentunya Pemkab Bangli tidak mengeluarkan biaya investasi, sehingga nilai LCC dalam perhitungan tarifnya tidak memasukkan biaya investasi awal, sedangkan sebagai penggantinya adalah memasukkan nilai investasi yang akan diperlukan untuk pembangunan kembali PLTS Bangli pada tahun 2033. Biaya pembangunan PLTS rata-rata mengalami penurunan sebesar $7.5 \%$ pertahun, untuk dapat membangun kembali PLTS dengan kapasitas 1 MWp pada tahun 2033 akan diperlukan biaya investasi sebesar Rp.5.257.444.097,--

\section{B. Life Cycle Cost (LCC) PLTS Bangli}

Komponen LCC terdiri dari biaya investasi, operasional dan maintenance, penggantian peralatan, sewa lahan dan asuransi dengan jumlah sebagai berikut : (PV : Present value)

- Jumlah PV biaya investasi $2012=$ Rp. 25.000.000.000

- Jumlah PV biaya investasi $2033=\mathrm{Rp}$. 5.257.444.097

- Jumlah PV biaya O \& M = Rp. 3.423.453.654

- Jumlah PV biaya penggantian alat = Rp. 4.855.725.412

- Jumlah PV biaya sewa lahan = Rp. 2.445.324.039

- Jumlah PV biaya asuransi = Rp. 1.528 .327 .524

Untuk selanjutnya perhitungan akan dibuat dalam dua skenario yaitu skenario-1 dan skenario-2. Jadi hasil perhitungan LCC nya adalah sebagai berikut :

- Present value LCC skenario-1 = Rp. 37.252.830.679

- Present value LCC skenario-2= Rp. 17.510.274.725

\section{Total Energi Listrik yang Dibangkitkan}

Data pembangkitan energi yang tersimpan pada remote monitoring system PTLS Bangli adalah mulai dari tanggal 15 Pebruari 2013 sampai dengan tanggal 25 Desember 2014. Dari data tersebut didapatkan hasil perhitungan rata-rata pembangkitan energi pertahunnya adalah 1.125.010 kWh. Data teknis sel surya memberikan jaminan bahwa degradasi pembangkitan energinya adalah $20 \%$ ( dua puluh persen ) dalam 25 tahun. Dalam 20 tahun yaitu sampai tahun 2032, akan terjadi degradasi sehingga hanya mampu menghasilkan energi sebesar $84.175 \%$, atau produksi energi pada tahun 2032 adalah sebesar 946.884,20 kWh dan komulatif produksi energi PLTS Bangli sampai tahun 2032 adalah sebesar 20,718,951.37 kWh, sedangkan total present value pembangkitan energi listriknya adalah $8,591,900.15 \mathrm{kWh}$.

\section{Levelized Cost of Energi (LCoE) PLTS Bangli}

Dengan menggunakan persamaan 2 dan memasukkan present value dari life cycle cost dibagi dengan present value total energi yang dibangkitkan, maka didapatkan hasil perhitungan $L C o E$. Perhitungan $L C o E$ skenario-1, yaitu dengan biaya investasi awal didapatkan hasil sebesar Rp. $4.336 / \mathrm{kWh}$ dan skenario-2 tanpa biaya investasi awal didapatkan hasil sebesar Rp. 2.035/kWh.

\section{E. Keekonomian Tarif PLTS Bangli}

Perhitungan tarif penjualan listrik adalah dengan menambahkan margin keuntungan sebesar $8 \%$ dari perhitungan LCoE. Margin keuntungan 8\% adalah yang umum dipergunakan oleh PLN.

Perhitungan tarif penjualan listrik mengikuti hasil $L C o E$ yaitu dibuat dalam 2 (dua) skenario, skenario-1 dan skenario-2. Hasil perhitungan skenario-1 ditampilkan dalam Tabel 1. 
TABEL I

PERHITUNGAN TARIF LISTRIK SKENARIO-1

\begin{tabular}{|c|c|c|}
\hline No. & Item & Unit price \\
\hline \multirow[t]{15}{*}{ I } & Present value Life Cycle Cost & \\
\hline & A. Initial Invesment (installed system) cost & \\
\hline & Present value investment cosh in 2012 & Rp.25.000.000.000,- \\
\hline & B. Fuel Cost & 0 \\
\hline & C. Fixed cost Operasional dan spare part & \\
\hline & a. Present value $O \& M$ & Rp. 3.423.453.654,- \\
\hline & b. Present value penggantian inverster & Rp. 4.855.725.412,- \\
\hline & Present value fixed cost O\&M & Rp. 8.279.179.066,- \\
\hline & D. Transmission cost & \\
\hline & Present value transmission cost & 0 \\
\hline & E. Other cost & \\
\hline & a. Present value sewa lahan & Rp. 2.445.324.039,- \\
\hline & b. Present value biaya asuransi & Rp. 1.528.327.524,- \\
\hline & F. Present value other cost & \\
\hline & Present value Life Cycle Cost & Rp.37.252.830.629,- \\
\hline \multirow[t]{2}{*}{ II } & Present Value Energy Generation & \\
\hline & Present value life time energy generation & kWh $8.591 .900,15$ \\
\hline \multirow[t]{2}{*}{ III } & Levelized Cost Of Energy $(\mathrm{LCoE})$ & \\
\hline & $\begin{array}{l}L C o E(\text { Biaya Energi })=P V L C C / P V \\
\text { Energy Generation }\end{array}$ & $\mathrm{Rp} / \mathrm{kWh}$ \\
\hline \multirow[t]{3}{*}{ IV } & Tarif Penjualan Listrik (TPL) & \\
\hline & $\begin{array}{l}\mathrm{TPL}=\mathrm{LCoE} \text { (biaya energi) }+ \text { Margin } \\
\text { keuntungan }(8 \%)\end{array}$ & $\mathrm{Rp} / \mathrm{kWh}$ \\
\hline & & $\mathrm{US} \$ / \mathrm{kWh}$ \\
\hline
\end{tabular}

Perhitungan tarif penjualan listrik skenario-1, didapatkan hasil bahwa penambahan nilai $L C O E$ dengan margin keuntungan sebesar 8\% maka tarif penjualan listriknya menjadi Rp. 4.683,- /kWh dengan nilai kurs 1 US $\$=$ Rp.13.500,- maka setara dengan US \$ 35 Sen/ kWh. Harga ini jauh diatas harga patokan tertinggi dari Kepmen no. 17 Tahun 2013 ( Us \$ $30 / \mathrm{kWh}$ ) sehingga tidak layak untuk diajukan. Tetapi dilihat dari segi biaya investasi sebesar Rp. 25.000.000.000,- , maka tarif listrik yang akan mampu mengembalikan investasi tersebut adalah tarif skenario-1 sebesar Rp. 4.683,- , akan tetapi karena PLTS Bangli merupakan pilot project yang dihibahkan ke Pemkab Bangli maka ada sasaran lain yang ingin dicapai pemerintah sehingga pengembalian investasi tidak menjadi hal yang utama. Hal ini sangat bebeda dengan proyek yang murni IPP.

Tabel 2 adalah perhitungan tarif penjulan listrik skenario-2, didapatkan hasil bahwa menambahkan nilai $L C o E$ dengan margin keuntungan sebesar $8 \%$, maka tarif penjualan listrik menjadi Rp. 2.201,- /kWh dengan nilai kurs 1 US $\$=$ Rp.13.500,- maka setara dengan US \$ 16 sen/kWh. Harga ini berada di bawah patokan harga tertinggi kebijakan FiT yang nilainya US \$ $25 \mathrm{sen} / \mathrm{kWh}$.

Dengan mengabaikan biaya investasi awal dan memasukkan biaya investasi yang akan diperlukan pada tahun 2033 maka tarif skenario-2, tidak akan mampu mengembalikan biaya investasi awal tetapi sudah mengandung seluruh LCC ditambah margin keuntungan bagi pengelola dan juga ada alokasi biaya untuk pembangunan kembali PLTS Bangli pada tahun 2033.
TABEL III

PERHITUNGAN TARIF LISTRIK SKENARIO-2

\begin{tabular}{|c|c|c|}
\hline No. & Item & Unit price \\
\hline \multirow[t]{15}{*}{$\mathbf{I}$} & Present value Life Cycle Cost & \\
\hline & A. Initial Invesment (installed system) cost & \\
\hline & Present value investment cosh in 2012 & Rp. 5.257.444.097,-- \\
\hline & B. Fuel Cost & 0 \\
\hline & C. Fixed cost Operasional dan spare part & \\
\hline & a. Present value O\&M & Rp. 3.423.453.654,- \\
\hline & b. Present value penggantian inverster & Rp. 4.855.725.412,- \\
\hline & Present value fixed cost O\&M & Rp. 8.279.179.066,- \\
\hline & D. Transmission cost & \\
\hline & Present value transmission cost & 0 \\
\hline & E. Other cost & \\
\hline & a. Present value sewa lahan & Rp. 2.445.324.039,- \\
\hline & b. Present value biaya asuransi & Rp. 1.528.327.524,- \\
\hline & F. Present value other cost & \\
\hline & Present value Life Cycle Cost & Rp.17.510.274.725,- \\
\hline \multirow[t]{2}{*}{ II } & Present Value Energy Generation & \\
\hline & Present value life time energy generation & kWh $8.591 .900,15$ \\
\hline \multirow[t]{2}{*}{ III } & Levelized Cost Of Energy $(\mathrm{LCoE})$ & \\
\hline & $\begin{array}{l}\text { LCoE }(\text { Biaya Energi })=P V L C C / P V \\
\text { Energy Generation }\end{array}$ & $\mathrm{Rp} / \mathrm{kWh}$ \\
\hline \multirow[t]{3}{*}{ IV } & Tarif Penjualan Listrik (TPL) & \\
\hline & $\begin{array}{l}\mathrm{TPL}=\mathrm{LCoE} \text { (biaya energi) }+ \text { Margin } \\
\text { keuntungan }(8 \%)\end{array}$ & $\mathrm{Rp} / \mathrm{kWh}$ \\
\hline & & US\$/kWh \\
\hline
\end{tabular}

\section{F. Total Harga Energi Listrik yang Dibangkitkan}

Dengan mempergunakan tarif penjualan listrik skenario-1 yang bernilai Rp. 4.683,- $/ \mathrm{kWh}$ dan total pembangkitan energi sebanyak $8.591 .900 \mathrm{kWh}$, memberikan hasil perhitungan total penjualan energi sebesar Rp. 97.020.069.914,-.

Dengan tarif penjualan listrik skenario-2 sebesar Rp. $2.201 / \mathrm{kWh}$, total hasil penjualan energinya adalah Rp.45.603.194.425,-

\section{G. Studi Kelayakan Ekonomi}

Untuk menganalisa kelayakan ekonomi terhadap tarif penjualan listrik dengan nilai Rp. 2.201,- /kWh dilakukan dengan mempergunakan 4 (empat) parameter yang hasil perhitungannya dapat diuraikan sebagai berikut.

1) Parameter Pay Back Period: Dengan mempergunakan persamaan 3, hasil perhitungan parameter PBP memperlihatkan bahwa untuk pengembalian LCC diperlukan waktu 19 tahun 1 bulan 18 hari, hal ini menunjukkan bahwa dengan tarif penjulan listrik Rp. 2.201,- / $/ \mathrm{kWh}$ bisa diterima karena total LCC dari PLTS Bangli akan bisa ditutupi sebelum habis masa kontraknya (20 tahun).

2) Parameter Net Present Value: Perhitungan parameter NPV dilakukan dengan mempergunakan persamaan 4, dengat tarif penjualan listrik Rp. 2.201,- / $\mathrm{kWh}$ didapatkan hasil nilai NPV yang bernilai positif yaitu 1.400.821.978,-. Dengan nilai yang positif ini, maka parameter NPV menunjukkan hasil yang bisa diterima dan layak dilaksanakan. 
3) Parameter IRR: IRR dihitung dengan mempergunakan persamaan 5, hasil perhitungannya IRR sebesar $12,536 \%$, angka ini lebih besar dari tingkat suku bunga $10.815 \%$, dengan demikian tarif penjualan listrik ini bisa diterima dan layak untuk diterapkan..

4) Parameter PI: Dengan mempergunakan persamaan 6, didapatkan hasil perhitungan parameter profitability index atau benefit cost ratio sebagai berikut, dimana :

$$
\begin{array}{ll}
\text { PV Pendapatan } & =\text { Rp. 18.911.096.703,- } \\
\text { PV Pengeluaran } & =
\end{array}
$$

maka :

$$
\begin{aligned}
P I & =\frac{18.911 .096 .703,-}{17.510 .274 .725,-} \\
& =1,080
\end{aligned}
$$

Hasil perhitungan 1,080 adalah lebih besar atau di atas 1 (satu), sesuai dengan kriteria parameter profitability index hasil diatas satu berarti tarif penjualan listrik Rp. 2.201,-/kWh adalah layak untuk diterima.

\section{SIMPULAN}

Simpulan terhadap kajian Analisa Keekonomian Tarif Penjualan Listrik Pembangkit Listrik Tenaga Surya 1 Mwp Bangli Dengan Metode Life Cycle Cost adalah sebagai berikut :

1. Hasil perhitungan tarif penjualan listrik skenario-1, yaitu dengan memasukkan biaya investasi dalam perhitungan LCC nya mendapatkan hasil sebesar Rp. $4.683 / \mathrm{kWh}$ (US $\$ 35 \mathrm{sen} / \mathrm{kWh}$ ) kalau dilihat dari Permen no. 17 tahun 2013, menunjukkan bahwa perhitungan tarif penjualan listrik ini jauh diatas harga patokan tertinggi yang besarnya US \$ 30 sen/kWh, sehingga tidak memungkinkan untuk memberlakukan hasil ini.

2. Hasil perhitungan tarif penjualan listrik skenario-2, yaitu dengan tidak memasukkan biaya investasi, dengan pertimbangan bawa ini adalah project hibah, maka didapatkan hasil tarif penjualan listrik sebesar Rp. 2.201 $/ \mathrm{kWh}$ (US \$ $16 \mathrm{sen} / \mathrm{kWh}$ ), kalau dilihat dari Permen no. 17 tahun 2013, menunjukkan bahwa perhitungan tarif penjualan listrik ini berada dalam range harga patokan tertinggi yang besarnya US \$ $25 \mathrm{sen} / \mathrm{kWh}$, sehingga sangat layak untuk diajukan dan diterima.

3. Studi kelayakan ekonomi terhadap tarif penjualan listrik skenario-2 (Rp. 2.201/kWh) dengan menggunakan empat parameter kelayakan ekonomi menunjukkan hasil yang menerima harga tersebut, ini berarti bahwa secara ekonomi tarif penjualan listrik ini memberikan profit kepada pengelola.

4. Diperlukan adanya keputusan yang tepat dan cepat dalam penetapan tarif penjualan listrik PLTS Bangli untuk dapat menjaga kontinuitas fungsi sistem dari aset yang dimiliki pemerintah untuk dapat tercapainya target pada tahun 2025 bauran pembangkit energi baru terbarukan sebesar $23 \%$.

\section{UCAPAN TERIMA KASIH}

Terima kasih penulis ucapkan kepada Ketua Program Studi Magister Teknik Elektro, Bidang Studi Manajemen Energi
Program Pascasarjana Universitas Udayana yang telah merekomendasikan untuk melaksanakan penelitian di PLTS Bangli, dan juga terima kasih kepada Direktur Pesusda Bukti Mukti Bhakti Bangli yang telah memberikan ijin bagi penulis untuk melaksanakan penelitian di PLTS Bangli.

\section{REFERENSI}

[1] Peraturan Pemerintah Republik Indonesia Nomor 79 Tahun 2014, Kebijakan Energi Nasional, Jakarta 17 Oktober 2014.

[2] Republik Indonesia, "Blueprint Pengelolaan Energi Nasional 2006 2025", Sesuai Peraturan Presiden Nomor 5 Tahun 2006, Jakarta, 2006.

[3] Kumara, I.N.S; Ariastina, W.G; Sukereyasa, I.W; Giriantari I.A.D, On the potensial and progress of renewable electricity generation in Bali, 2014 6Th Internationaal Conference in Technologiy and Electrical Engineering (ICITEE), vol. no. pp1-6, 7-8 Oct 2014.

[4] Peraturan Menteri Energi Dan Sumber Daya Mineral Republik Indonesia Nomor: 17 Tahun 2013 Tentang Pembelian Tenaga Listrik Oleh Pt Perusahaan Listrik Negara (Persero) Dari Pembangkit Listrik Tenaga Surya Fotovoltaik.

[5] Ashadi, Perumusan Tariff Pembelian Listrik Pada Regulasi Feed in Tariff untuk Teknologi Photovoltaic Serta Analisa Penerapannya di indonesia. Tesis Program Magister, Fakultas Teknik.

[6] I K Agus Setiawan, I N Satya Kumara, I Wayan Sukerayasa, Teknik Analisis Unjuk Kerja Pembangkit Listrik Tenaga Surya (Plts) Satu MWP Terinterkoneksi Jaringan di Kayubihi Bangli. Jurnal Teknologi Elektro: Vol 13, No 1 (2014): (January -- June) : Journal of Electrical Technology.

[7] Norberto Soares, "Studi Tarif Listrik Dengan Menggunakan Metode Long Run Marginal Cost Di Edtl Timor Leste" (Tesis), Program Magister Program Studi Teknik Elektro Program Pascasarjana Universitas Udayana Denpasar, 2013.

[8] Ambarsari Lisa, Penentuan Tarif Listrik Berdasarkan Metode Revenue Requirement Dan Metode Biaya Marjinal Jangka Panjang, Tesis UI Jakarta.

[9] Puspitowati Wulan Diah, 2013. Penggunaan Metode Life Cycle Cost Analysis (LCCA) Untuk Penghitungan Efisiensi Energi Pada Gedung Depo Penyimpan Arsip Di Lembaga Arsip Nasional Republik Indonesia, Tesis UGM Jogjakarta.

[10] Mitchell Leckner, Radu Zmeureanu, Life cycle cost and energy analysis of a Net Zero Energy House with solar combisystem, Applied Energy Volume 88, Issue 1, January 2011, Pages 232-241.

[11] National Bureau of Standards. 1980. Life cycle cost manual for the Federal Energy Management Program. National Bureau of Standards handbook 135. U.S. Department of Commerce, Washington, D.C.

[12] B.S. Dhillon, "Life Cycle Costing For Engineers", Crc Press, Taylor \& Francis Group, 6000 Broken Sound Parkway Nw, Suite 300 Boca Raton, Fl 33487-2742, 2010.

[13] Christoph Kost, Johannes N Mayer, Jessica Thomsen, Niklas Hartmann, Charlotte Senkpiel, Simon Philipps, Sebastian Nold, Simon Lude, Noha Saad, Thomas Schlegl, Levelized Cost of Electricity Renewable Energy Technologies Study, Edition: November 2013, Fraunhofer. 